\title{
Do Bt Transgenic Events Alter the Phenotypic Stability of Maize Hybrids?
}

\author{
Rafael Parreira Diniz ${ }^{*}$, Renzo Garcia Von Pinho', José Airton Rodrigues Nunes, \\ Lívia Maria Chamma Davide², Adriano Delly Veiga ${ }^{3}$, João Cândido de Souza1 \\ ${ }^{1}$ Departmento de Biologia, Universidade Federal de Lavras, Lavras, Brazil \\ ${ }^{2}$ Faculdade de Ciências Agrárias/FCA, Universidade Federal da Grande Dourados/UFGD, Dourados, Brazil \\ ${ }^{3}$ Empresa Brasileira de Pesquisa Agropecuária-EMBRAPA CERRADOS, Planaltina, Brazil \\ Email: ${ }^{*}$ rafadiniz rpd@yahoo.com.br, renzo@dag.ufla.br, jarnunes@dbi.ufla.br, liviadavide@ufgd.edu.br, \\ adriano.veiga@embrapa.br, cansouza@dbi.ufla.br
}

Received 21 August 2015; accepted 12 September 2015; published 15 September 2015

Copyright (C) 2015 by authors and Scientific Research Publishing Inc.

This work is licensed under the Creative Commons Attribution International License (CC BY).

http://creativecommons.org/licenses/by/4.0/

c) (7) Open Access

\section{Abstract}

Transgene insert location in the genome through different methods is random. Thus, alterations in the expression of desired trait may occur, as well as alterations in the expression of other characteristics of receptor plant. The purpose of this study was to compare $B t$ transgenic maize hybrids and the respective conventional isogenic hybrid in relation to adaptability and phenotypic stability. Field trails were set up in four locations of Minas Gerais, Brazil (Campo do Meio, Lavras, Madre de Deus and Paraguaçu). A randomized complete block design was used, with three replications, and the treatment structure was a factorial $6 \times 2$, with six hybrids in the transgenic and conventional versions. Plant and ear height and grain yield were evaluated. To estimate stability, the Anicchiarico, Wricke and AMMI methodologies were used. Grain yield and ear height of the transgenic hybrids and their respective conventional isogenic hybrid did not differ. There are differences in the phenotypic stability between transgenic hybrids with $B t$ technology and their counterpart conventional isogenic hybrid.

\section{Keywords}

Zea mays, Insect Resistance, Genotype $\times$ Environment Interaction

\section{Introduction}

In 2014, biotechnological crops occupied 42.2 million hectares in Brazil [1], with the area planted to transgenic

\footnotetext{
${ }^{*}$ Corresponding author.
}

How to cite this paper: Diniz, R.P., Von Pinho, R.G., Nunes, J.A.R., Davide, L.M.C., Veiga, A.D. and de Souza, J.C. (2015) Do Bt Transgenic Events Alter the Phenotypic Stability of Maize Hybrids? American Journal of Plant Sciences, 6, 2309-2316. 
maize with the Bt gene at approximately 12.5 million hectares. Rapid adoption of this technology by Brazilian producers has been observed in consideration of the fact that the first varieties of genetically modified maize were released for planting in 2008.

$B t$ maize cultivars are obtained through insertion of a determined gene of the Bacillus thuringiensis bacteria by biolistic device or by Agrobacterium tumefaciens in the genome of this species [2]. In these two plant transformation systems, the location of insertion of the desired gene in the plant genome is at random.

Random insertion of the gene may sometimes result in alterations in the DNA sequence to be inserted and may sometimes alter the genome of the receptor [3] [4]. Thus, alterations in the expression of desired characteristics may occur, as well as alterations in the expression of other characteristics of receptor plants [4] [5]. Morphological alterations in various crops are described in the literature, such as rice [6], soybeans [7], cotton [8] and maize [9].

Another aspect of interest in studies with transgenic cultivars with the Bt gene is associated with the genotype by environment interaction ( $\mathrm{GxE}$ ), which is directly associated with the analyses of phenotypic stability of the cultivars.

The GxE interaction is characterized when the behavior of breeds, inbred lines or cultivars is not consistent in the different environments, i.e., the responses of the genotypes are different in the face of alterations that occur in the environments [10]. The nature of the interaction must be attributable to physiological and biochemical factors belonging to each cultivar. In genetic terms, the interaction may occur when the contribution of the genes that control the trait or its level of expression differ among the environments. This occurs because the gene expression is affected and/or regulated by the environment [11].

Analyses of stability seek to evaluate the reaction of a genotype in relation to other genotypes in different environments [12]. Differences in insect and disease resistance may be associated with the stable or unstable performance of the cultivar [13]. Thus, Kang [13] reports that if the GxE interaction were caused by damages from the European Corn Borer (Ostrinia nubilalis), a gene conferring resistance to this pest, for example Bt, could be inserted in the plants. That way, greater stability could be conferred to the genotype. As such, Blanche et al. [8] comparing transgenic cotton cultivars with the respective non-transgenic isogenic lines, observed that there are differences in the levels of phenotypic stability in accordance with the characteristic analyzed and the event used. In the literature, results comparing transgenic maize hybrids with the respective non-transgenic isogenic lines in regard to adaptability and phenotypic stability are scarce.

In light of the above, the purpose of this study was to compare transgenic maize hybrids with the respective non-transgenic isogenic hybrid in relation to agronomic traits and the phenotypic stability.

\section{Material and Methods}

The experiments were conducted in the summer 2009/2010 crop season in a no-till system in four locations in the southern region of Minas Gerais, Brazil: Campo do Meio (850 m altitude, $21^{\circ} 05^{\prime} \mathrm{S}$ and $45^{\circ} 34^{\prime} \mathrm{W}$ ), Lavras

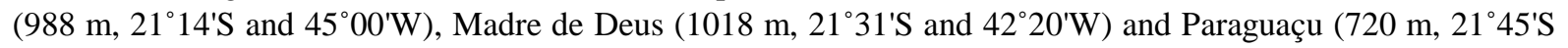
and $45^{\circ} 15^{\prime} \mathrm{W}$ ).

Six single hybrids were evaluated (AG8060, AG8088, DKB185, IMPACTO, MAXIMUS and P30F53), in the transgenic versions with the Bt gene and conventional versions. The AG8060, AG8088, DKB185 and P30F53 transgenic hybrids belong to the group of cultivars with the MON810 event. The Impacto and Maximus hybrids, for their part, also in the transgenic version, are derived from the BT11 event. The hybrids belong to different Seed Companies in Brazil. They were selected because they were available in the seed market in both conventional and transgenic versions in the season 2009/2010. A randomized complete block design with three replications was used. The treatment structure was a factorial $6 \times 2$, with six hybrids and two types, transgenic and conventional versions. Plots consisted of four five-meter length rows spaced at $0.80 \mathrm{~m}$. The two center rows were considered to be useful for data collection. Density was five plants per linear meter after thinning, equivalent to 62,500 plants per hectare.

At sowing time, $450 \mathrm{~kg} \cdot \mathrm{ha}^{-1}$ of the formula $8(\mathrm{~N}): 28\left(\mathrm{P}_{2} \mathrm{O}_{5}\right): 16\left(\mathrm{~K}_{2} \mathrm{O}\right)$ was used. Top-dressing fertilization was carried out when the plants were in the stage of 4 - 5 fully expanded leaves, with the application of $300 \mathrm{~kg} \cdot \mathrm{ha}^{-1}$ of the formula $30(\mathrm{~N}): 00\left(\mathrm{P}_{2} \mathrm{O}_{5}\right): 20\left(\mathrm{~K}_{2} \mathrm{O}\right)$.

Plant height, ear height and grain yield characteristics were evaluated. Evaluation of plant height as well as ear height was undertaken with the aid of a measuring tape, measuring five plants per plot. Plant height was 
measured from ground level up to the base of the tassel and ear height from ground level up to the base of the first ear node.

Grain yield was determined after harvest, shelling of the ears and weighing the grain. Moisture content was determined immediately after harvest and the yield, quantified in $\mathrm{kg}$, was adjusted to the value of $13 \%$ moisture content and expressed in $\mathrm{kg} \cdot \mathrm{ha}^{-1}$.

For the grain yield trait, with a view toward correcting irregularities in stand, analysis of covariance was carried out according to Ramalho et al. [14]. Average yields of the plots, in all the experiments, were corrected to ideal stand (50 plants $\left./ 8 \mathrm{~m}^{2}\right)$.

Before undertaking individual and joint statistical analyses, an analysis for all the traits evaluated was undertaken for the purpose of verifying if there were statistical differences between the transgenic events MON810 e BT11 used in this experiment.

Analyses of individual variances were made for all the characteristics evaluated. Subsequently, joint analyses were also made.

Before undertaking joint analyses, the homogeneity of the residual variances among the environments was checked by means of the ratio between the greatest and least mean square error of the environments. The variances were considered homogeneous when the value was less than seven, in accordance with Pimentel Gomes [15]. That way joint analysis of variance of the data may be performed.

Individual and joint analyses were undertaken by means of the "GLM" (General Linear Models) procedure of the SAS v 8.0 statistical computing package [16]. Mean values were grouped by means of the Scott-Knott test at $5 \%$ probability using the Genes computing package [17].

To estimate hybrid stability (conventional and transgenic), the Anicchiarico [18], Wricke [19] and AMMI (Additive Main Effects and Multiplicative Interaction Analysis) methods were chosen [20] [21]. These methods were chosen for providing easily interpretable results.

AMMI uses ordinary ANOVA to analyze the main effects (additive part) and Principal Component Analysis (PCA) to analyze the non-additive residual left over by the ANOVA [21]. The interaction is the genotype PCA score multiplied by that of the environment. When a genotype and environment have the same sign on their respective first PCA axis, their interaction is positive, if different, their interaction is negative. An AMMI plot is a graph where aspects of both genotypes and environments are plotted on the same axis so that interrelationship can be visualized. It provides a pictorial view of the transformed $\mathrm{G} \times \mathrm{E}$ interaction [21] for any interpretation. In a biplot where IPCA1 is on the vertical axis and mean yield on the horizontal, genotypes that appear almost on a perpendicular line had similar means and those that fall almost on a horizontal line had similar interaction patterns. Genotypes or environments with large IPCA1 scores, either positive or negative had large interactions, whereas genotypes with IPCA1 score of zero or nearly zero had smaller interactions [21]. The biplot of the first two IPCA axis demonstrates the relative magnitude of the GEI for specific genotypes and environments. The further away from the axis center genotype or environment is, the larger the genotype $\times$ environment interaction

To verify the significance of the hybrid stability provided by the method of Wricke [19], $\left(\mathrm{H}_{0}: \mathrm{W}_{i}^{2}=0\right)$, the statistical test proposed by Lisbão Júnior was used [22]. However, the tester was altered by the mean square error, which is justified by the hybrid $\mathrm{x}$ location interaction being of a fixed nature in the present study.

\section{Results and Discussion}

By means of analysis of variance of the characteristics evaluated, more specifically of the contrast test, it was observed that the MON810 and BT11 events were not statistically different between themselves (data not shown). That way it was inferred that the events may be considered as having equal effects. They were thus grouped in a single category ( $B t$ transgenics), belonging to the "types" source of variation, for later performance of statistical analyses.

By means of joint analyses of variance involving the four experiments, significance $(\mathrm{P}<0.05)$ was observed for the diverse sources of variation for all the characteristics evaluated (Table 1). It was observed that these significant sources were common for the parameters evaluated, plant height and ear height, with the exception of “Types" for plant height.

It may be verified that the Locations source of variation was significant for the three traits evaluated (Table 1). Results like this are common since each location has different edaphoclimatic conditions. Consequently, these may have a different effect on performance of the hybrids evaluated. 
For the Types variation source, significance shows that there were differences between transgenic and conventional hybrids in relation to plant height (Table 1). It was observed that transgenic plants with Bt technology were larger than the plants without this technology, with mean values of $231 \mathrm{~cm}$ and $227 \mathrm{~cm}$ respectively (Table 2). The comparative analysis of the values of plant height, ear height and grain yield did not show significant differences between the transgenic hybrids and the respective isogenic hybrid [23].

Significance of the Hybrid $\times$ Types interaction shows that hybrid performance in relation to plant height and ear height depends on the version (transgenic or conventional). It was verified that the hybrid P30F53, in the transgenic version, had greater plant height than its respective conventional version (Table 2). Similar results were reported by Magg et al. [9]. The authors concluded that transgenic plants of Bt maize, when grown under controlled conditions, were larger in relation to the plants of the respective conventional versions. The hybrids DKB185 and P30F53, in the transgenic version, had greater ear height in relation to the respective conventional isogenic lines (Table 2).

For the plant height, ear height and grain yield characteristics, significance was verified for the interaction between Locations x Hybrids (Table 1). It is known that plant development may be different according to the prevailing climatic conditions in the different locations of evaluation. It may thus be affirmed that at least one hybrid had better performance for the characteristics evaluated in at least one location.

The Types source of variation for grain yield was not significant $(\mathrm{P} \geq 0.05)$ (Table 1). This result indicates

Table 1. Summary of joint analyses of variance involving the four locations for plant height and ear height and grain yield, of transgenic hybrids and their respective conventional versions.

\begin{tabular}{|c|c|c|c|c|c|c|c|}
\hline \multirow{2}{*}{ FV } & \multirow{2}{*}{ GL } & \multicolumn{2}{|c|}{ Plant height } & \multicolumn{2}{|c|}{ Ear height } & \multicolumn{2}{|c|}{ Grain yield } \\
\hline & & QM & $\operatorname{Pr}>\mathbf{F}$ & QM & $\operatorname{Pr}>\mathbf{F}$ & QM & $\operatorname{Pr}>$ F \\
\hline Locations (L) & 3 & 5363.19 & $<0.0001$ & 2320.54 & $<0.0001$ & $48,657,015.3$ & $<0.0001$ \\
\hline Blocks/L & 8 & 154.68 & 0.1468 & 50.86 & 0.7558 & $688,066.6$ & 0.6550 \\
\hline Hybrids (H) & 5 & 212.08 & 0.0673 & 47.25 & 0.7156 & $1,910,755.4$ & 0.0782 \\
\hline Types (T) & 1 & 667.36 & 0.0110 & 126.56 & 0.2162 & 3,538,976.1 & 0.0541 \\
\hline $\mathrm{H}^{*} \mathrm{~T}$ & 5 & 1087.3 & $<0.0001$ & 461.14 & 0.0001 & $1,344,499.5$ & 0.2151 \\
\hline$\left(\mathrm{G}^{*} \mathrm{~A}\right)$ & (33) & & & & & 1,184,304.15 & 0.1843 \\
\hline $\mathrm{L}^{*} \mathrm{H}$ & 15 & 307.36 & 0.0004 & 233.74 & 0.0011 & $1,713,737.9$ & 0.0403 \\
\hline $\mathrm{L}^{*} \mathrm{~T}$ & 3 & 65.05 & 0.5799 & 158.97 & 0.1275 & 1,474,326.9 & 0.1980 \\
\hline $\mathrm{L}^{*} \mathrm{H}^{*} \mathrm{~T}$ & 15 & 296.71 & 0.0007 & 208.55 & 0.0033 & $597,234.8$ & 0.8311 \\
\hline Error & 88 & 98.81 & & 81.54 & & $928,340.8$ & \\
\hline CV (\%) & & \multicolumn{2}{|c|}{4.32} & \multicolumn{2}{|c|}{7.25} & \multicolumn{2}{|c|}{13.68} \\
\hline Mean & & \multicolumn{2}{|c|}{229} & \multicolumn{2}{|c|}{124} & \multicolumn{2}{|c|}{7039.25} \\
\hline
\end{tabular}

Table 2. Mean values of transgenic maize hybrids and of their respective non-transgenic isogenic hybrid in reference to the plant height, ear height and grain yield traits, obtained by means of joint analysis of the four locations.

\begin{tabular}{|c|c|c|c|c|c|c|c|c|c|}
\hline \multirow{2}{*}{ Hybrids } & \multicolumn{3}{|c|}{ Plant height } & \multicolumn{3}{|c|}{ Ear height } & \multicolumn{3}{|c|}{ Grain yield } \\
\hline & Conv & Trans & Mean & Conv & Trans & Mean & Conv & Trans & Mean \\
\hline AG8060 & $231 \mathrm{~A}$ & $232 \mathrm{~A}$ & 230 & $122 \mathrm{~A}$ & $126 \mathrm{~A}$ & 123 & 7546 & 8493 & 8019 a \\
\hline AG8088 & $231 \mathrm{~A}$ & $236 \mathrm{~A}$ & 234 & $124 \mathrm{~A}$ & $126 \mathrm{~A}$ & 125 & 8371 & 8790 & 8581 a \\
\hline DKB185 & $228 \mathrm{~A}$ & $240 \mathrm{~A}$ & 232 & $117 \mathrm{~B}$ & $131 \mathrm{~A}$ & 123 & 8204 & 8461 & $8332 \mathrm{a}$ \\
\hline Impacto & $231 \mathrm{~A}$ & $230 \mathrm{~A}$ & 226 & $127 \mathrm{~A}$ & $123 \mathrm{~A}$ & 126 & 7593 & 8284 & 7939 a \\
\hline Maximus & $231 \mathrm{~A}$ & $232 \mathrm{~A}$ & 228 & $131 \mathrm{~A}$ & $120 \mathrm{~A}$ & 126 & 8188 & 7942 & 8065 a \\
\hline P30F53 & $226 \mathrm{~B}$ & $236 \mathrm{~A}$ & 227 & $119 \mathrm{~B}$ & $126 \mathrm{~A}$ & 122 & 8655 & 8469 & 8562 a \\
\hline Mean & $227 \mathrm{~B}$ & $231 \mathrm{~A}$ & & 123 & 125 & & 8093 & 8406 & \\
\hline
\end{tabular}

${ }^{*}$ Mean values followed by the same small letter in the column and capital letter in the line belong to the same grouping by the Scott-Knott test at $5 \%$ probability. 
that performance of the hybrids, both conventional and transgenic, were similar. Similar results were obtained in studies carried out in the United States and Brazil [23] [24]. When the yield of similar cultivars is compared, transgenic and conventional, it is observed that, controlling other factors, in conditions where there is no pressure of pests and/or insects from the environment on crop development, the yield of the conventional crop is equal to or slightly higher than the yield of the crop with transgenic [24].

The interaction between Hybrids $\times$ Types for grain yield was also not significant $(P \geq 0.05)$ (Table 1$)$. That shows the performance of transgenic hybrids with the $B t$ gene is similar to that of their respective conventional isogenic hybrid (Table 2). These results are also in agreement with those found by Graeber et al. [25], Ma and Subedi [26] and Laserna et al., [27]. Nevertheless, Magg et al. [9] undertaking a study in two environments, one with pest control and another without any corn worms infestation, reported that in both the experiments, the transgenic hybrids had a greater yield than the counterpart isogenic hybrid. Generally, Bt corn hybrids out yielded their non-Bt hybrids by $13 \%$ - 23\% when European corn borer infestation was severe [28].

In Brazil, a rapid increase has been observed in substitution of conventional hybrids for hybrids with $B t$ technology. Consequently, a tendency of rising costs for hybrid seeds is noted, which may make its adoption unviable for a large group of farmers. An increase in the cost of transgenic seeds with the $B t$ gene is observed in the order of US $\$ 40.00$ to US $\$ 80.00$ per bag when compared to the same seed without the $B t$ technology. Thus, it is important to take into consideration at the time of recommending the hybrid if the use of the $B t$ technology will compensate the greater seed cost.

The mean values, the estimates of ecovalence $\left(W_{i}^{2}\right)$, of the relative contribution of each genotype to the interaction $\left(C R_{i}\right)$ by the method of Wricke [19] and of the confidence index $\left(I_{i}\right)$, the mean of the percentages of each hybrid in the four environments $\left(p_{i}\right)$ and the standard deviation $\left(s_{i}\right)$ of each hybrid, by the method of Anicchiarico [18], for grain yield of transgenic maize hybrids and the respective conventional isogenic hybrid, are presented in Table 3.

It may be observed that the hybrid Maximus showed the greatest relative contribution to the interaction, $18.8 \%$ in the transgenic version, and also showed the lowest contribution, with $2.7 \%$ in the conventional version (Table 3). That way, in the transgenic version, this hybrid has less stability in relation to the respective non-transgenic isogenic hybrid. This result may be explained as a result of the non-coincidence of the performance of this hybrid in the different locations of evaluation. The hybrids AG8088 and P30F53 in the transgenic version also had a greater relative contribution to the interaction, exhibiting less stability. In contrast, the hybrids AG8060, DKB185 and Impacto exhibited less stability in the conventional version.

By means of the modified test of Lisbão Júnior at 5\% probability, it was observed that only the Maximus hybrid with $B t$ technology contributed in a significant manner to the interaction. Thus, this hybrid was not consi-

Table 3. Mean values and estimates of the parameters of phenotypic stability by means of the methods of Anicchiarico (1992) and Wricke (1965) for grain yield of transgenic and conventional maize hybrids.

\begin{tabular}{|c|c|c|c|c|c|c|}
\hline \multirow{2}{*}{ Hybrids } & \multirow{2}{*}{ Type $^{*}$} & \multicolumn{2}{|c|}{ Wricke } & \multicolumn{3}{|c|}{ Anicchiarico } \\
\hline & & $W_{i}^{2}$ & $C R_{i}(\%)$ & $p_{i}$ & $S_{i}$ & $I_{i}$ \\
\hline AG8060 & $\mathrm{C}$ & $2,326,610.2$ & 5.9 & 85.8 & 7.31 & 90.7 \\
\hline AG8060 & $\mathrm{T}$ & $1,594,549.7$ & 4.1 & 99.7 & 4.9 & 103.0 \\
\hline AG8088 & $\mathrm{C}$ & $2,838,238.4$ & 7.2 & 97.7 & 6.2 & 101.9 \\
\hline AG8088 & $\mathrm{T}$ & 4,369,838.9 & 11.2 & 101.1 & 9.4 & 107.4 \\
\hline DKB 185 & $\mathrm{C}$ & 6,002,182.6 & 15.3 & 95.1 & 6.3 & 99.3 \\
\hline DKB 185 & $\mathrm{~T}$ & 2,301,399.3 & 5.9 & 95.6 & 10.6 & 102.8 \\
\hline Impacto & $\mathrm{C}$ & 3,139,719.2 & 8.0 & 85.3 & 8.9 & 91.3 \\
\hline Impacto & $\mathrm{T}$ & $1,487,945.4$ & 3.8 & 96.7 & 5.0 & 100.1 \\
\hline Maximus & $\mathrm{C}$ & $1,064,817.3$ & 2.7 & 96.2 & 4.3 & 99.1 \\
\hline Maximus & $\mathrm{T}$ & 7,351,156.1 & $18.8^{* *}$ & 88.5 & 11.0 & 95.9 \\
\hline P30F53 & $\mathrm{C}$ & $1,585,016.8$ & 4.1 & 101.4 & 5.3 & 105.0 \\
\hline P30F53 & $\mathrm{T}$ & $5,039,089.0$ & 12.9 & 97.2 & 8.8 & 103.2 \\
\hline
\end{tabular}

${ }^{*} \mathrm{C}$ - conventional; T—transgenic; ${ }^{* *}$ Significant by the test of Lisbão Júnior at 5\% probability. 
dered stable while the others were considered stable.

According to the confidence index of Anicchiarico [18], at the 25\% level of significance, in the worst of hypotheses, the hybrids AG8060 and AG8088 in the transgenic version had performance 3.5\% and 9\% superior to the mean of the environment (Table 3). It is also observed that the Maximus hybrid in the transgenic and conventional versions, even under favorable environmental conditions, had performance $1.1 \%$ and $4.8 \%$ below the mean of the environment.

In relation to AMMI analysis, it was observed that only the first main component (CP1) of the decomposition of the GxE interaction was significant, explaining $58.75 \%$ of the square sum of the interaction. It may be inferred that this axis concentrates the greatest proportion of the differential response pattern of the hybrids according to the locations.

The AMMI diagram (Figure 1) shows that the hybrids, AG8060 transgenic and Impacto transgenic stood out with lower scores of the $\mathrm{CP} 1$, indicating that they contributed less to the interaction. Thus, these hybrids were more stable.

The hybrids AG8060 and Impacto in the transgenic version were more stable in relation to the respective conventional isogenic hybrid when compared by the three methods proposed. This result may be explained in terms of these hybrids with $B t$ technology being more tolerant to pest attack. Phenotypic stability for grain yield depends on various plant characteristics, among them, grain yield itself and resistance to insect pests [29]. Nevertheless, when the $B t$ gene is inserted in the genome of maize plants, it is expected that they are capable of bearing a greater pest attack, maintaining the same yield when compared to plants without this gene. Similar results were reported by Blanche et al. [8] when the authors compared Bt transgenic cotton cultivars with the respective conventional isogenic lines. The authors concluded that the transgenic cultivars were more stable than the conventional cultivars for the plant height characteristic and percentage of linters, among others.

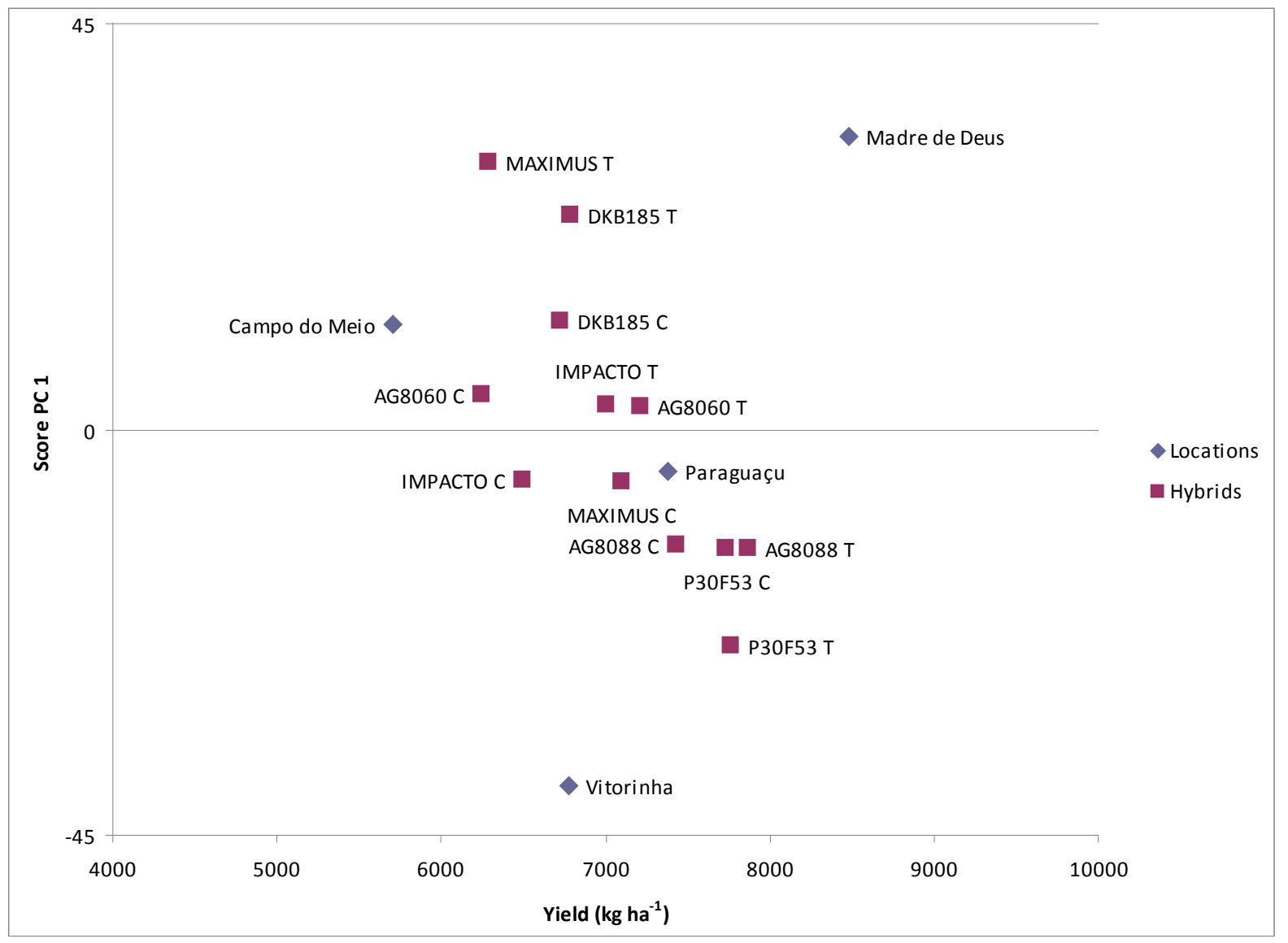

Figure 1. Biplot AMMI 1 of the contribution to relative interaction to the first axis of analysis of the main components of the six hybrids in the transgenic (T) and conventional (C) versions and of the four locations of evaluation. 
In this research, it was seen that the phenotypic stability was different for some maize hybrids when compared transgenic hybrids and the conventional isogenic hybrid. However, it does not allow us to conclude that transgenic hybrids are more stable than conventional hybrids as proposed by Kang [13]. In that way, more researches are needed to be done to verify if there is difference in the phenotypic stability among transgenic and conventional hybrids.

\section{Conclusions}

Plant height of the hybrids varies according to the type of hybrid (conventional or transgenic); in general, the transgenic hybrids have greater plant heights than the conventional hybrids.

Grain yield and ear height of the transgenic hybrids and their respective conventional isogenic hybrid were similar.

There are differences in the phenotypic stability between transgenic hybrids with $B t$ technology and their respective conventional isogenic hybrid.

\section{Acknowledgements}

To Fundação de Amparo à Pesquisa do Estado de Minas Gerais, Conselho Nacional de Desenvolvimento Cientifico e Tecnológico e Coordenação de Aperfeiçoamento de Pessoal de Nível Superior, for supporting this research.

\section{References}

[1] James, C. (2014) Global Status of Commercialized Biotech/GM Crops. ISAAA, Ithaca. (ISAAA Brief, n. 49).

[2] Twyman, R.M., Christou, P. and Stöger, E. (2002) Genetic Transformation of Plants and Their Cells. In: OksmanCaldentey, K.M. and Barz, W.H., Eds., Plant Biotechnology and Transgenic Plants, M. Dekker, New York, 111-141. http://dx.doi.org/10.1201/9780203910849.ch6

[3] Visarada, K.B.R.S., Meena, K., Aruna, C., Srujana, S., Saikishore, N. and Seetharama, N. (2009) Transgenic Breeding: Perspectives and Prospects. Crop Science, 49, 1555-1563. http://dx.doi.org/10.2135/cropsci2008.10.0581

[4] Scott, M.P. and Pollak, L.M. (2005) Transgenic Maize. Starch, 57, 187-195. http://dx.doi.org/10.1002/star.200400396

[5] Wang, F., Peng, S., Cui, K., Nie, L. and Huang, J. (2014) Field Performance of Bt Transgenic Crops: A Review. Australian Journal of Crop Science, 8, 18-26.

[6] Lynch, P.T., Jones, J., Blackhall, N.W., Davey, M.R., Power, J.B., Cocking, E.C., Nelson, M.R., Bigelow, D.M., Orum, T.V., Orth, C.E. and Schuh, W. (1995) The Phenotypic Characterization of R2 Generation Transgenic Rice Plants under Field and Glasshouse Conditions. Euphytica, 85, 395-401. http://dx.doi.org/10.1007/BF00023972

[7] Liu, W., Torisky, R.S., Mallister, K.P., Avdiushko, S., Hildebrand, D. and Collins, G.B. (1996) Somatic Embryo Cycling: Evaluation of a Novel Transformation and Assay System for Seed-Specific Gene Expression in Soybean. Plant Cell Tissue Organ Culture, 47, 33-42. http://dx.doi.org/10.1007/bf02318963

[8] Blanche, S.B., Myers, G.O., Zumba, J.Z., Caldwell, D. and Hayes, J. (2006) Stability Comparisons between Conventional and Near-Isogenic Transgenic Cotton Cultivars. Journal of Cotton Science, 10, 17-28. http://journal.cotton.org

[9] Magg, T., Melchinger, A.E., Klein, D. and Bohn, M. (2001) Comparison of Bt Maize Hybrids with Their Non-Transgenic Counterparts and Commercial Varieties for Resistance to Europea Corn Borer and for Agronomic Traits. Plant Breeding, 120, 397-403. http://dx.doi.org/10.1046/j.1439-0523.2001.00621.x

[10] Ramalho, M.A.P., Santos, J.B., Pinto, C.A.B.P., Souza, E.A., Gonçalves, F.M.A. and Souza, J.C. (2012) Genética na agropecuária. 5 Edition, UFLA, Lavras.

[11] Kang, M.S. (1998) Using Genotype by Environment Interaction for Crop Cultivar Blending Ability in AOT. Crop Science, 41, 199-252.

[12] Bernardo, R. (2010) Breeding for Quantitative Traits in Plants. 2nd Edition, Stemma Press, Woodbury.

[13] Kang, M.S. (2002) Genotype-Environment Interaction: Progress and Prospects. Quantitative Genetics, Genomics and Plant Breeding. CAB International.

[14] Ramalho, M.A.P., Ferreira, D.F. and Oliveira, A.C. (2012) Experimentação em genética e melhoramento de plantas. 3rd Edition, UFLA, Lavras.

[15] Pimentel-Gomes, F. (2009) Curso de estatística experimental. 15th Edition, FEALQ, Piracicaba. 
[16] Statistical Analysis Software Institute (2000) SAS/STAT Software. Version 8.0. Cary.

[17] Cruz, C.D. (2013) Programa GENES: Estatística experimental e matrizes. UFV, Viçosa.

[18] Anicchiarico, P. (1992) Cultivar Adaptation and Recommendation from Alfafa Trials in Northern Italy. Journal Genetics and Breeding, 46, 269-278.

[19] Wricke, G. (1965). Zur berechning der okovalenz bei sommerweizen und hafer. Zeitschrift fur Pflanzenzuchtung, 52, 127-138.

[20] Gauch, H.G. and Zobel, R.W. (1996) AMMI Analysis of Yield Trials. In: Kang, M.S. and Gauch, H.G., Eds., Genotype by Environment Interaction, CRC Press, Boca Raton, 85-122. http://dx.doi.org/10.1201/9781420049374.ch4

[21] Duarte, J.B. and Vencovsky, R. (1999) Interação genótipos x ambientes: Uma introdução à análise “AMMI”. Sociedade Brasileira de Genética, Ribeirão Preto.

[22] Resende, M.D.V. (2002) Genética biométrica e estatística no melhoramento de plantas perenes. Embrapa Informação Tecnológica, Brasília.

[23] Ferreira, F.S., Nozawa, S.R. and Souza, J.C. (2015) Consequences of Gene Stacking by Hybridization in Transgenic Plants. Euphytica (Online), 10. http://dx.doi.org/10.1007/s10681-015-1464-6

[24] Gianessi, L.P. and Carpenter, J.E. (1999) Agricultural Biotechnology: Inset Control Benefits. National Center for Food and Agricultural Policy, Washington DC.

[25] Graeber, J.V., Nafzinger, E.D. and Mies, D.W. (1999) Evaluation of Transgenic Bt-containing Corn Hybrids. Journal Production Agricultural, 12, 659-663. http://dx.doi.org/10.2134/jpa1999.0659

[26] Ma, B.L. and Subedi, K.D. (2005) Development, Yield, Grain Moisture and Nitrogen Uptake of Bt Corn Hybrids and Their Conventional Near-Isolines. Fields Crops Research, 93, 199-211. http://dx.doi.org/10.1016/j.fcr.2004.09.021

[27] Laserna, M.P., Maddonni, G.A. and López, C.G. (2012) Phenotypic Variations between Non-Transgenic and Transgenic Maize Hybrids. Field Crops Research, 134, 175-184. http://dx.doi.org/10.1016/j.fcr.2012.06.005

[28] Mungai, N.W., Motavalli, P.P., Nelson, K.A. and Kremer, R.J. (2005) Differences in Yields, Residue Composition and N Mineralization Dynamics of Bt and Non-Bt Maize. Nutrient Cycling in Agroecosystems, 73, 101-109. http://dx.doi.org/10.1007/s10705-005-8850-8

[29] Kang, M.S. and Magari, R. (1996) New Developments in Selecting for Phenotypic Stability in Crop Breeding. In: Kang, M.S. and Gauch Junior, H.G., Eds., Genotype by Environment Interaction, Elsevier, New York, 11-14. 